\title{
PENGARUH PEMBERIAN PEGAGAN (Centela asiatica) TERHADAP TITER ANTIBODI DAN BERAT BADAN AYAM BROILER
}

\author{
Prima Silvia Noor ${ }^{1 a), ~ Y u r n i ~ S a r i ~ A m i r ~}{ }^{1)}$, Muthia Dewi ${ }^{2)}$ dan Toni Malvin²) \\ 1) Program Studi Paramedik Veteriner Politeknik Pertanian Negeri Payakumbuh, \\ 2) Program Studi Budi Daya Ternak Politeknik Pertanian Negeri Payakumbuh, Jl. \\ aEmail: primasilvianoor@yahoo.com
}

\begin{abstract}
Poultry products from such as broiler chicken usually contain residues because in the maintenance of chicken used medicinal ingredients, both to prevent disease and increase body weight. This study was aimed to determine the ability of pegagan plan (Centella asiatica) as natural feed additive to stimulate the body weight of chicken. The experiment was run in completely randomized design which consist of 4 feed treatments and 5 replications. Level used of $A=$ without pegagan powder; $B=1.5 \%$ pegagan powder; $C=3 \%$ pegagan powder dan $D=$ $4.5 \%$ pegagan powder. The result shown that body weight was significantly different $(P<0.05)$ but not for HI ND was no significantly different $(P>0.05)$. The higher of body weight of chicken shown in D parameter (level $4.5 \%$ pegagan powder) was $944.0 \mathrm{~g}$. Pegagan influences a vasodilation to increase blood flow of chicken which has an impact on increasing body metabolism, so that it becomes an acceleration of body weight gain in broiler chickens.
\end{abstract}

Keywords: pegagan powder, residue, chicken broiler, body weight, HI ND

\section{PENDAHULUAN}

Harapan masyarakat terhadap bahan pangan asal hewan yang aman, utuh, sehat dan halal (ASUH) memerlukan penanganan hewan semenjak dari farm. Ayam broiler merupakan salah satu sumber protein harus diusahakan agar tidak mengandung penyakit, namun juga tidak boleh ditemukan residu bahan kimia di dalam dagingnya. Obat dan bahan lain yang digunakan sebagai bahan pencegahan dan pengobatan ditujukan untuk menjaga kesehatan dan produktivitas ayam. Apabila pemberian bahan tersebut tidak mengikuti aturan penggunaan obat dapat berdampak lain bagi konsumen dan menimbulkan penolakan pada pemasaran.

Kesehatan hewan ternak dapat dijaga melalui pertahanan tubuh aktif dari berbagai penyakit seperti vaksinasi. Dari proses stimulasi oleh vaksin pada pembentukan bahan pertahanan tubuh, terbentuklah globulin yang sesuai vaksin pada serum darah, selanjutnya akan berperan aktif menangkal penyakit yang masuk sampai ke dalam tubuh. Pembentukan imuno globulin (Ig) dipengaruhi oleh beberapa hal dalam waktu dan jumlahnya (titer), seperti ketersediaan asam amino sebagai bahan Ig itu dan bahan yang mampu merangsang (stimulansia) atau bahan yang menekan (depresansia). Namun juga ada bahan yang mampu memodulasi (modulator) titernya di dalam darah sehingga kehadirannya mengakibatkan keseimbangan Ig. Salah satu bahan 
alami yang disebutkan sebagai imunostimulansia adalah tumbuhan pegagan (Centella asiatica) (Sembiring, 2011).

Suryani dan Ayu (2014), menyebutkan bahwa Centella asiatica pada mencit mampu meningkatkan total sel darah putih secara signifikan dan meningkatkan kemampuan fagositosis makrofag terhadap pembersihan karbon. Hal tersebut menunjukkan bahwa bahan yang terdapat pada tumbuhan tersebut merangsang proses pembentukan pertahanan tubuh.

Pertahanan tubuh yang baik akan memberi harapan pada peningkatan produktivitas usaha ayam broiler dimana diberikan jaminan keamanan pangan asal hewan. Melalui pemberian tepung pegagan ke dalam ransum basal pada pemeliharaan ayam broiler, dilakukan penelitian mengenai Pengaruh Pemberian Pegagan (Centela asiatica) terhadap Titer Antibodi dan Berat Badan Ayam Broiler.

Tujuan dari penelitian ini adalah untuk mengetahui kemampuan pemberian Pegagan (Centella asiatica) dalam meningkatkan titer Antibodi dan Pertambahan Badan Ayam Broiler.

\section{MATERI DAN METODE PENELITIAN}

\section{Tempat dan Waktu}

Penelitian ini dilaksanakan bertempat di Laboratorium Produksi Ternak Politeknik Pertanian Negeri Payakumbuh. Berlangsung dari bulan Juli sampai September 2018.

\section{Materi Penelitian}

Ayam yang dipakai adalah ayam sebanyak 100 ekor. Ayam dibagi menjadi empat kelompok perlakuan (A, B, C dan D). Tiap kelompok diulang 5 kali. Kelompok A; ransum basal dengan $0 \%$ tepung pegagan, kelompok $\mathrm{B}$; ransum basal dengan 1,5\% pegagan, kelompok $\mathrm{C}$; ransum basal dengan $3 \%$ pegagan dan kelompok D; ransum basal dengan 4,5\% pegagan.

\section{Metode Pelaksanaan}

Ayam dipelihara sejak umur satu hari. Sampai umur 7 hari diberikan ransum starter komersial. Pada hari ke 4 dilakukan vaksinasi ND Lasota. Dalam masa 10 hari setelah vaksinasi diambil serum dari vena ulnaris pada sayap. Kemudian dilakukan uji HI (hemolisis inhibition) titer Antibodi (Ab) ND. Sementara untuk mengetahui pertambahan berat badan dilakukan penimbangan terhadap ayam setiap minggu. Pertambahan berat badan diakumulasi pada minggu ke 4, saat ayam dipanen.

Penelitian dirancang dalam rancangan acak lengkap, hasil dianalisa menggunakan SPSS analisis.

\section{HASIL DAN PEMBAHASAN}

\section{Titer Antibodi}

Dari pengamatan yang dilakukan (Tabel 1), diperoleh titer Antibodi ND pada semua kelompok $(A, C, B$ dan $D)$. Secara tidak nyata $(\mathrm{P}<0,05)$ pegagan tidak mempengaruhi titer antibodi. Hal ini menunjukkan bahwa titer antibodi ditentukan oleh vaksinasi. Namun bila dicermati dari kelompok A (pemberian 
pegagan $0 \%$ ) titer antibodinya adalah $6,2 \log 2$ berada di atas standar, namun persentase kekebalan berada pada $60 \%$, dimana batasnya $\geq 80 \%$. Sedangkan pada kelompok B dan D berturut-turut titernya adalah 8,2 dan 7,8 log2. Hal ini menunjukkan bahwa pemberian pegagan $(1,5$ dan 4,5$) \%$ menaikkan titer Antibodi ND melampaui standar dimana tingkat kekebalan mencapai $100 \%$. Kandungan triterpenoid dari pegagan diperkirakan memberi peranan pada kejadian ini. Senyawa asiaticoside yang terkandung dalam triterpenoid merupakan salah satu jenis antibiotik alami dan juga berpotensi sebagai imunomodulator. Senyawa asiaticoside banyak terkumpul di bagian daun Centella asiatica (Suryani dan Ayu, 2014). Asiaticoside yang masuk ke dalam tubuh mengaktifkan makrofag dan granulosit sehingga dapat meningkatkan fagositosis. Dibandingkan hasil penelitian Lutfi dkk (2010) yang menggunakan levamisole, titer antibodi menggunakan pegagan masih sedikit lebih rendah, dimana hasil yang diperoleh menggunakan levamisole memperoleh rata-rata 8,42 .

Tabel 1. Titer Antibodi ND ayam broiler pada pemberian pegagan

\begin{tabular}{ccccc}
\hline Parameter & A & $\mathbf{B}$ & $\mathbf{C}$ & $\mathbf{D}$ \\
& $\mathbf{( 0 \% )}$ & $\mathbf{( 1 , 5 \% )}$ & $\mathbf{( 3 \% )}$ & $\mathbf{( 4 , 5 \% )}$ \\
\hline Titer Antibodi $(\log 2)$ & 6,2 & 8,2 & 5,8 & 7,8 \\
\hline
\end{tabular}

Ganong (2003) dan Guyton \& Hall (1997), menjelaskan bahwa dalam proses pembentukan Antibodi, makrofag sebagai sel $\mathrm{T}$ terlebih dahulu akan melakukan fagositosis terhadap Antigen, selanjutnya memberi sinyal kepada sel B. Kemudian sel B akan membentuk Imunoglobulin (Ig), yang tidak lain adalah antibodi itu sendiri. Aktivitas fagositosis dinamakan sistem imun seluler dan pembentukan Ig adalah sistem imun humoral. Aktivasi makrofag tidak hanya menunjukkan peningkatan fagositosis tapi juga merubah sel sekretori sebagai sel efektor sitotoksis. Hal tersebut sering dapat menstimulasi atau bahkan menekan sistem imun humoral dan selular.

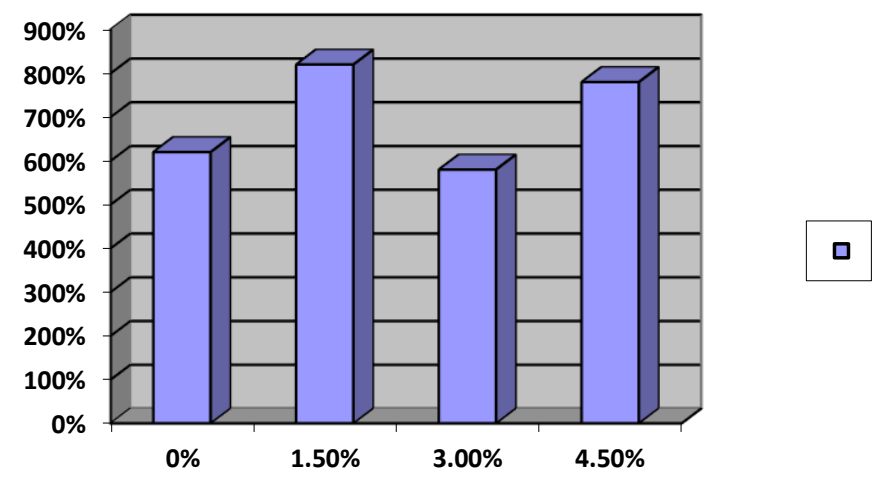

Gambar 1. Grafik titer antibodi ND ayam broiler pada pemberian pegagan

Pegagan memperlihatkan pengaturan sistem imun. Pemberian pada kadar 3\% (kelompok C) terlihat bahwa titer antibodi menurun menjadi 5,8 (Gambar 1). Bahan yang terkandung di dalamnya melakukan modulasi. Imunomodulator dapat membantu untuk regulasi atau menormalkan kembali sistem imun. Imunomodulator memperbaiki kembali sistem imun yang tidak 
seimbang, memperbaiki sistem imun yang lemah, dan sistem imun yang terlalu aktif tetapi tidak meningkatkan sistem imun seperti yang dilakukan oleh imunostimulant. (Sembiring, 2011) memperlihatkan potensi minuman pegagan dan asitaba sebagai antioksidan yang menginduksi respon imun.

Mustikasari (2015), membuktikan pada penelitiannya bahwa pemberian kombinasi ekstrak pegagan dan bluntas yang diberikan kepada tikus dengan dosis rendah menurunkan kadar enzim Glutamat Piruvat transaminase (GPT), enzim yang dikeluarkan ketika terjadi nekrosis (kematian sel) atau pada peningkatan permiabilitas sel. Herlina (2010), memperlihatkan pada penelitiannya bahwa asitikosida pegagan $160 \mathrm{mg} / \mathrm{kg}$ berat badan mengakibatkan peningkatan penumpukan lemak hepar namun tidak mengakibatkan kebocoran sel hepar, dan diperkirakan oleh adanya kandungan flavonoid pada pegagan yang bertindak sebagai antioksidan.

\section{Berat Badan Ayam}

Pemberian pegagan pada ransum ayam broiler memperlihatkan peningkatan berat badan pada konsentrasi 1,5\% (kelompok B) dan 4,5\% (kelompok D) dan tidak berbeda terhadap kontrol (kelompok A, 0\%) dan; Sejalan dengan pengaruh titer antibodi, pada konsentrasi pegagan $3 \%$ (kelompok C), pertambahan berat badan paling rendah dari semua perlakuan (Tabel 2).

Tabel 2. Pertambahan berat badan ayam broiler pada pemberian pegagan

\begin{tabular}{ccccc}
\hline Parameter & $\begin{array}{c}\text { A } \\
\mathbf{0 \% )}\end{array}$ & $\begin{array}{c}\text { B } \\
\mathbf{( 1 , 5 \% )}\end{array}$ & $\begin{array}{c}\mathbf{C} \\
\mathbf{( 3 \% )}\end{array}$ & $\begin{array}{c}\mathbf{D} \\
\mathbf{( 4 , 5 \% )}\end{array}$ \\
\hline Pertambahan Berat Badan (gr) & 852 & 844 & 809.25 & 870 \\
\hline
\end{tabular}

Perbedaan pertambahan berat badan ayam broiler dari level pemberian pegagan menandakan kandungan pegagan mempengaruhi energi pakan. Sutardi (2016), menyatakan bahwa pegagan mengandung bahan aktif alkaloid, saponin, tanin, flavonoid, steroid, dan triterpenoid. Diperkirakan bahan tersebut meningkat vasodilatasi sehingga meningkatkan metabolisme. Tanaman pegagan juga mengandung garam mineral antara lain kalium, natrium, magnesium, kalsium, dan besi, fosfor, minyak atsiri, pektin, asam amino, vitamin B, dan zat pahit vellarine. Bahan-bahan tersebut sangat dibutuhkan dalam proses biokimiawi tubuh seperti pembentukan enzim dan hormon. Selanjutnya, dengan adanya kesempurnaan enzim dan hormon meningkatan nafsu makan, memperbaiki metabolisme dan mendorong pembentukan konformasi tubuh.

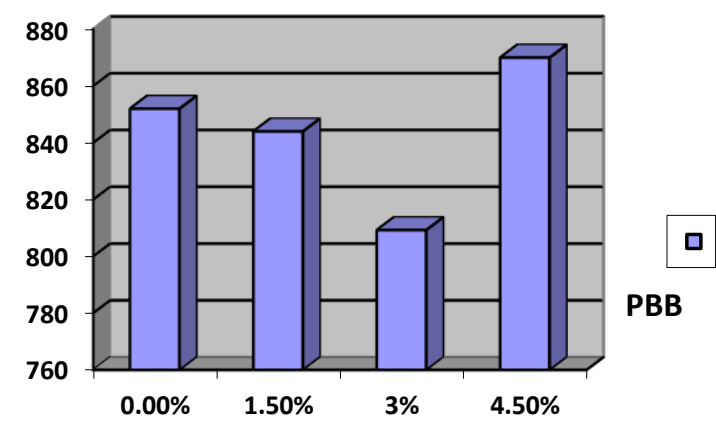

Gambar 2. Grafik pertambahan berat badan ayam broiler pada pemberian pegagan 
Selanjutnya pada kelompok D (pemberian pegagan 4,5\%) menunjukkan pertambahan berat badan paling tinggi (Gambar 2). Hal ini menguatkan bahwa kandungan pegagan yang tinggi meningkatkan berat badan, selain itu kandungan protein pada daun pegagan juga mempengaruhi pertambahan berat badan ayam. Kadar kandungan aktif pegagan triterpenoid berpengaruh kepada aktivitas bahan tersebut (Mora dan Fernando, 2012).

\section{KESIMPULAN DAN SARAN}

Dari hasil dan pembahasan dapat disimpulkan bahwa pemberian pegagan berpengaruh terhadap berat badan secara signifikan $(\mathrm{P}<0.05)$. Namun tidak berbeda nyata terhadap titer antibodi. Berat badan tertinggi diperoleh pada kelompok D (level pemberian 4,5\%). Titer antibodi tertinggi diperoleh pada kelompok B dengan level pemberian 1,5\%.

\section{DAFTAR PUSTAKA}

Ganong, W.F. 2003. Buku Ajar Fisiologi Kedokteran. Penerbit Buku Kedokteran EGC. Jakarta.

Guyton, A.C. 1997. Buku Ajar Fisiologi Kedokteran. Penerbit Buku Kedokteran EGC. Jakarta.

Herlina. 2010. Pengaruh Senyawa Murni dari Pegagan (Centella asiatica (L) Urban) terhadap Fungsi Kognitif Belajar dan Mengingat dan Efek Toksisitas pada Mencit (Mus musculus) Betina. Makalah Seminar. Jurusan Kimia FMIPA Universitas Sriwijaya.

Lutfi, U.M., Malvin, T. and Irda, I., 2010. Pemberian Imunostimulant Levamisole Dalam Meningkatkan Titer Antibodi Pasca Vaksinasi Avian Influenza Pada Ayam Petelur. LUMBUNG, 9(02), pp.207-216.

Mora, E. dan A. Fernando. 2012. Optimasi Ekstraksi Triterpenoid Total Pegagan (Centella asiatica (Linn.) Urban) yang Tumbuh di Riau. Jurnal Penelitian Farmasi Indonesia. 1(1), September 2012: 11-16

Mustikasari, W. 2015. Pengaruh Kombinasi Ekstrak Daun Pegagan (Centella asiatica (L) Urban) dan Daun Beluntas (Plucea indica (L) Less) terhadap Kadar Enzim Transaminase dan Gambaran HistologiHepar Tikus Putih (Ratus norvegicus) Betina. Skripsi. Fakultas sains dan Teknologi. Universitas Islam Negeri (UIN) Maulana Malik Ibrahim. Malang.

Sutardi. 2016. Kandungan Bahan Aktif Tanaman Pegagan Dan Khasiatnya Untuk Meningkatkan Sistem Imun Tubuh. Jurnal Litbang Pertanian Vol. 35 No. $3: 121-130$

Widjajakusuma, E.C. W.D. Tamayanti, L. Hendriati, I.S. Hamid, Ferawati, A Surjadhana, dan A. Jonosewojo. 2012. Efek Antikanker Mammae Dari Ekstrak Centella Asiatica Dan Andrographis Paniculata: Suatu Rangkuman Studi Aktivitas Secara In Vitro And In Vivo. 